\title{
Changes in the properties of pig manure slurry*
}

\author{
Zygmunt Kowalski ${ }^{凶}$, Agnieszka Makara and Kamil Fijorek² \\ ${ }^{1}$ Cracow University of Technology, Institute of Chemistry and Inorganic Technology, Kraków, Poland; ${ }^{2}$ Cracow University of Economics, Departa- \\ ment of Statistics, Kraków, Poland
}

\begin{abstract}
The paper presents the results of analyses of samples of manure from a pig farm located near Piła, Poland performed between June 2011 and May 2012 using a single sampling system. The statistical analyses of the average content of chemical and biological oxide demands, nitrogen, phosphorus, potassium, calcium and dry mass in the slurry in various seasons allowed us to draw conclusions concerning the changes in the chemical composition of the manure in specific seasons and to determine the correlations between the chemical parameters. The average content of $\mathrm{N}, \mathrm{BOD}, \mathrm{P}$, and dry mass content tended to decrease systematically from the spring until the winter. The highest correlation coefficient, which indicates significant interdependency among the variables tested, was consistently found for COD and BOD, whereas the smallest correlation coefficient was found consistently for $\mathrm{K}$ and $\mathrm{Ca}$ and once for $\mathrm{Ca}$ and $\mathrm{N}$.
\end{abstract}

Key words: pig slurry, swine/pigs, chemical composition, fertilizer components

Received: 24 October, 2013; revised: 04 December, 2013; accepted: 16 December, 2013

\section{INTRODUCTION}

Industrial pig breeding in Poland produces large amounts of pig manure slurry that according to the Polsh law (Act, 2007) is defined as fertilizer. The arable land fertilized with slurry, however, is diminishing, and the management of this waste is getting more and more problematic (Oudendag \& Luesink, 1998). On the average, 100 pigs produce daily $2846 \mathrm{~kg}$ of manure. In pig slurry, which is a mixture of urine, excrement, and water, two fractions can be distinguished: the liquid one, that consists primarily of nitrogen compounds, and the solid one, that consists of phosphorus and organic compounds (Kowalski et al., 2012; Lens et al., 2004). The amount of slurry produced is strictly associated with the size and age of the pigs as well as the method of keeping the animals. The total amount of slurry produced in the USA is assessed to be $1 \mathrm{Gt}$ per annum. This slurry contains approximately $5 \mathrm{Mt}$ of nitrogen, $3 \mathrm{Mt}$ of potassium, and $1.5 \mathrm{Mt}$ of phosphorus (Troeh \& Thompson, 1993; Taylor, 1994).

Intensive pig breeding contributes to changes in the natural environment due to acidification, eutrophication and an increasing greenhouse effect the emission of $\mathrm{CO}_{2}, \mathrm{CH}_{4}$, and $\mathrm{NO}_{x}$ ).

The chemical composition of pig manure depends on many factors, including the type and age of animals and a feeding method. Nitrogen is the component that determines the value of the specific slurry as a fertilizer. One-half of the nitrogen in pig slurry occurs in the form of easily soluble ammonium nitrogen. The amount of nitrogen in slurry decreases with time, and the difference between its total amount in fresh pig slurry and in pig slurry that has been stored for 90 days may be approximately $60 \%$. The total amount of phosphorus in slurry increases gradually and subsequently decreases to a value lower than that in fresh feces. Density of pig feces ranges between 900 and $1100 \mathrm{~g} / \mathrm{dm}^{3}$ (Hus \& Kutera, 1998). This density was analyzed by Czop (Czop, 2011) and it was equal to $886-889 \mathrm{~g} / \mathrm{dm}^{3}$, and the total nitrogen content ranged between 4.04 and $5.01 \mathrm{~g} / \mathrm{dm}^{3}$. These values are similar to the data presented elsewhere (Magrel, 2004; Krawczyk \& Walczak, 2010; Prapaspongsa, 2010).

Nitrogen in pig slurry occurs in organic and inorganic forms. The forms of nitrogen in slurry include ammonia, ammonium compounds, nitrates, nitric oxides, and organic matter (Rulkens et al., 1998; Bertora et al., 2008). Nitrogen in slurry is composed primarily of inorganic compounds, which constitute approximately $75 \%$ of the total amount of $\mathrm{N}$ (Prapaspongsa, 2010). A fertilizer derived from nursing or pregnant sows differs in composition from the slurry derived from the other specimens. Determination of the nitrogen content for different groups of pigs (Table 1) was investigated elsewhere(Sánchez \& González, 2005). Nursing and pregnant sows, together with piglets belonged to Group 1. Group 2 contained all the other specimens (both adult pigs and piglets). Pigs weighing between 14 and $16 \mathrm{~kg}$ (grower) and raised for slaughter were classified as Group 3.

Phosphorus compounds in the manure mainly occur in inorganic form (74-87\% of the total $\mathrm{P}$ content). The phosphorus content depends on the physiology of the animals from which the slurry is derived (Sánchez \& González, 2005).

Storage of manure is associated with the generation of odors produced due to anaerobic degradation of materials present in manure. Pig manure contains approximately 400 volatile organic and inorganic compounds of unpleasant odor, including hydrocarbons, aldehydes, ketones, alcohols, mercaptans, esters, phenols, cyclic amines, hydrogen sulfide, ammonia, and nitric oxides. The main sources of the odors are proteins, which are subjected to anaerobic decomposition resulting from the activity of putrefactive bacteria (Cotta et al., 2003; Hus \& Kutera, 1998; Pawełczyk \& Muraviev, 2003; Szynkowska \& Zwoździak, 2010) include Pseudomonas fluorescens, Bacil-

e-mail: zkow@chemia.pk.edu.pl

*Presented at the 5th Central European Congress of Life Sciences "EUROBIOTECH 2013", Kraków, Poland.

Abbreviations: COD, chemical oxygen demand; TKN, total nitrogen determined with Kjeldahl's method; BOD5, biochemical oxygen demand 
lus subtilis, and Bacillus cereus, as well as Clostridium sporogenes and Clostridium butyricum. The decomposition process resulting in the emission of malodorous gases applies, apart from proteins, to saccharides and lipids. Decomposition of lipids produces an increased amount of volatile fatty acids (from $\mathrm{C}_{4}$ to $\mathrm{C}_{12}$ ) (Kuczyński, 2002; Libudzisz, 2008).

Harmful microorganisms growing in pig manure slurry include bacteria, viruses, and other pathogens. The most common pathogenic bacteria include gram-negative anaerobic bacilli of the genera Enterobacter, Escherichia, Salmonella, and Proteus. Soils that are fertilized with manure containing solid parts cannot be deemed free from pathogens and indicatory organisms, including E-coli group bacteria, fecal streptococci, and Salmonella, for at least one year after fertilization (Rufete et al., 2006; Sorensen \& Amato, 2001). Low temperatures, high air humidity, and neutral soil generally contribute to the development and survival of enteric bacteria. The soil texture may also be changed (Głąb \& Gondek, 2008). Composting of separated pig manure resulted in organic matter transformation (Hsu \& Lo, 1999).

In the other study (Moral et al., 2005), slurry samples were collected from 36 commercial farms in Southeast Spain. Samples were analyzed for $\mathrm{pH}$, electrical conductivity (EC), redox potential, specific density, total solids, sedimentable solids, biological oxygen demand, chemical oxygen demand, total nitrogen, ammonium nitrogen (AN), organic nitrogen, and total contents of phosphorus, potassium, calcium and magnesium. Relationships between major nutrient levels of pig slurries and a range of physical and chemical properties were investigated. TKN, AN and $\mathrm{K}$ were closely related to EC. The P content in slurries was related more closely to solids-derived parameters. Pig manure could be a source of pollutants. The work (De la Torre et al., 2000) estimates the environmental risk in nine samples from different farm treatment systems based on the evaluation of their effects in Daphnia magna acute test, and on the assessment of $\mathrm{Cu}$, $\mathrm{Zn}$ and ammonia as main contributors.

This paper presents the results of tests conducted on the pig manure slurry obtained from a pig farm located near Piła, Poland. The analyses of the slurry were performed between June 2011 and May 2012 using a single sampling system. The tests performed throughout one year enabled us to determine changes in the slurry's chemical composition at different seasons of the year.

\section{MATERIALS AND METHODS}

The pig slurry collected between June 2011 and May 2012 at a pig farm located near the town of Piła, Poland was analyzed. The farm produces piglets intended for fattening at other pig farms, as well as sows for renewing the stock. The average monthly livestock statistics, by a pig type, were as follows: 1101 sows, 64 gilts, 2536 sucking piglets, 140 weaned piglets, 200 shoats, and 160 porkers. The total number of pigs was 4201 .

Pig manure samples were taken from drainpipe carrying the slurry from the pig farm to a lagoon according to the PN-B-12098:1997 standard. The same system and sample source were used throughout the study. Preparation and measurements of the samples were performed according to the proper polish standards (Kowalski et al., 2012) to determine the content of nitrogen, the biochemical oxygen demand, the chemical oxygen demand, and the content of phosphorus, potassium, calcium, and dry mass. To determine Kjeldahl nitrogen a DK6 digester and a steam distillation unit produced by VELP were used. Phosphorus was determined with a Nanocolor UV/VIS spectrophotometer produced by Machery-Nagel. A WSL M-9 digester produced by WSL was used to mineralize the samples to determine COD. Potassium and calcium were determined by flame atomic absorption spectroscopy (FAAS) using a Perkin Elmer OPTIMA 7300 DV apparatus. Microbiological tests were performed to identify Salmonella bacilli (according to the PN-Z-19000-1:2001P norm) and live parasite eggs.

Quantitative variables were characterized by the average value and standard deviation. The equality of average values in independent groups was tested using an analysis of variance (ANOVA). The correlation among quantitative variables was identified using a Pearson correlation coefficient and multiple regression, and $p<0.05$ was considered statistically significant. The analysis was conducted using a previously described program (R Development Core Team, 2010).

\section{RESULTS AND DISCUSSINON}

The properties of the pig manure analyzed in the long-term tests revealed changes in the chemical composition of slurry throughout the whole year. Because of the chemical composition being changed significantly, the average values of all determinations were calculated for slurry samples obtained in prescribed time intervals. All interpretations of the results were compared with the average values for a specific season.

The test results of all of samples of the pig manure are presented in Table 2. Table 3 presents the descriptive statistics of the variables tested (average and standard deviation). The matrix of the Pearson linear correlation coefficients is given in Table 4 , and Table 5 shows the results of the data analysis using the multiple regression model.

Figure 1 shows a series of charts presenting the changes in the content of a given parameter depending on the date of collection of the pig slurry sample. Because the samples were obtained between June 2011 and May 2012, the results are arranged in chronological order, to present changes in the slurry's properties from summer through autumn and winter to spring. The average results of the parameter determination at given time of year are identified using black line segments.

The analyses of the average values of nitrogen, biochemical oxygen demand, phosphorus, and dry mass show that the highest average values tended to occur in the spring, whereas the lowest average results were found in winter. The lowest average values were as follows: N $4.18 \mathrm{~g} / \mathrm{kg}$, BOD $14.98 \mathrm{~g} / \mathrm{kg}$, P $0.81 \mathrm{~g} / \mathrm{kg}$, and dry mass $39.05 \mathrm{~g} / \mathrm{kg}$. The highest average values were as follows: N $7.14 \mathrm{~g} / \mathrm{kg}$, BOD $25.48 \mathrm{~g} / \mathrm{kg}, \mathrm{P} 1.52 \mathrm{~g} /$ $\mathrm{kg}$, and dry mass $83.07 \mathrm{~g} / \mathrm{kg}$. A systematic decrease in $\mathrm{N}, \mathrm{BOD}, \mathrm{P}$, and dry mass occurred between spring and

Table 1. Average nitrogen content in pig manure from different specimens (Sánchez \& González 2005).

\begin{tabular}{lccc}
\hline $\begin{array}{l}\text { Nitrogen content }(\mathrm{g} / \mathrm{kg} \text { of } \\
\text { slurry) }\end{array}$ & Group 1 & Group 2 & Group 3 \\
\hline Ammonium $\left(\mathrm{NH}_{4}^{+}\right)$ & 1.50 & 1.69 & 2.43 \\
\hdashline Inorganic & 2.07 & 2.47 & 3.31 \\
\hdashline Organic & 0.67 & 0.70 & 0.88 \\
\hdashline Total & 2.61 & 3.07 & 4.08 \\
\hline
\end{tabular}


Table 2. Results of pig manure analysis.

\begin{tabular}{|c|c|c|c|c|c|c|c|c|c|c|c|}
\hline \multirow{2}{*}{$\begin{array}{l}\text { Batch } \\
\text { No. }\end{array}$} & \multirow{2}{*}{$\begin{array}{l}\text { Season of } \\
\text { the year }\end{array}$} & \multirow{2}{*}{$\begin{array}{l}\text { Sampling } \\
\text { date }\end{array}$} & \multicolumn{7}{|c|}{ Parameter determined $(\mathrm{g} / \mathrm{kg})$} & \multicolumn{2}{|c|}{ Microbiological tests } \\
\hline & & & $\mathrm{N}$ & $\mathrm{BOD}_{5}$ & COD & $P$ & $\mathrm{~K}$ & $\mathrm{Ca}$ & $\begin{array}{l}\text { Dry } \\
\text { mass }\end{array}$ & Salmonella & $\begin{array}{l}\text { Live eggs of } \\
\text { parasites }\end{array}$ \\
\hline 1 & \multirow{12}{*}{ Summer } & 06.06 .11 & 4.69 & 19.7 & 43.1 & 1.27 & 2.09 & 1.46 & 83.3 & absent & absent \\
\hline 2 & & 13.06 .11 & 7.69 & 34.1 & 67.5 & 1.67 & 3.16 & 1.61 & 86.1 & absent & absent \\
\hline 3 & & 20.06 .11 & 2.97 & 6.75 & 17.45 & 0.77 & 2.02 & 1.26 & 84.4 & present & present \\
\hline 4 & & 04.07 .11 & 6.71 & 37.2 & 91 & 2.18 & 1.45 & 1.94 & 78.4 & absent & absent \\
\hline 5 & & 11.07 .11 & 6.82 & 20.1 & 75.4 & 2.35 & 2.86 & 1.33 & 118 & absent & absent \\
\hline 6 & & 18.07 .11 & 12.9 & 16.7 & 43 & 1.89 & 1.71 & 1.67 & 80.1 & present & absent \\
\hline 7 & & 25.07 .11 & 4.4 & 10.4 & 38.6 & 0.83 & 1.43 & 1.98 & 60.2 & absent & absent \\
\hline 8 & & 01.08 .11 & 1.5 & 6.45 & 19.65 & 0.52 & 0.16 & 0.78 & 30 & absent & absent \\
\hline 9 & & 08.08 .11 & 3.11 & 10.5 & 20.8 & 0.64 & 1.31 & 2.04 & 68 & absent & absent \\
\hline 10 & & 16.08 .11 & 6.18 & 28.1 & 58 & 1.96 & 2.4 & 4.63 & 81.5 & absent & absent \\
\hline 11 & & 22.08 .11 & 4.37 & 25.25 & 53.4 & 0.91 & 1.92 & 1.32 & 40.5 & absent & absent \\
\hline 12 & & 29.08 .11 & 7.75 & 44.7 & 100.7 & 1.99 & 3.68 & 3.78 & 119 & absent & absent \\
\hline 13 & \multirow{11}{*}{ Autumn } & 05.09 .11 & 3.97 & 13.8 & 36.7 & 1.13 & 1.32 & 2.3 & 45 & absent & absent \\
\hline 14 & & 12.09 .11 & 5.39 & 14.5 & 29.6 & 0.55 & 2.41 & 1.13 & 33 & absent & absent \\
\hline 15 & & 19.09 .11 & 2.33 & 7.7 & 18.4 & 0.85 & 0.9 & 1.62 & 34 & absent & absent \\
\hline 16 & & 26.09 .11 & 3.23 & 7.05 & 14.95 & 0.22 & 1.09 & 1.51 & 29 & absent & absent \\
\hline 17 & & 03.10 .11 & 7.65 & 50.8 & 125.2 & 2.04 & 2.76 & 6.32 & 106 & absent & absent \\
\hline 18 & & 10.10 .11 & 7.65 & 32.2 & 118 & 1.52 & 3.26 & 1.57 & 109 & absent & absent \\
\hline 19 & & 17.10 .11 & 8.8 & 31.7 & 115.1 & 1.73 & 3.74 & 5.77 & 103 & absent & absent \\
\hline 20 & & 24.10 .11 & 5.15 & 13.75 & 32.65 & 0.27 & 2.12 & 0.75 & 25 & absent & absent \\
\hline 21 & & 31.10 .11 & 5.45 & 8.9 & 40.5 & 1,35 & 2.68 & 1.68 & 53 & absent & absent \\
\hline 22 & & 14.11 .11 & 8.73 & 36.9 & 87.9 & 1.66 & 2.13 & 2.44 & 109 & absent & absent \\
\hline 23 & & 28.11 .11 & 3.94 & 18.1 & 39.3 & 0.57 & 0.29 & 3.85 & 39 & absent & absent \\
\hline 24 & \multirow{6}{*}{ Winter } & 12.12 .11 & 3.68 & 9.62 & 20 & 0.46 & 0.71 & 1.11 & 21 & absent & absent \\
\hline 25 & & 27.12 .11 & 3.05 & 10.4 & 29 & 0.64 & 0.94 & 2.27 & 48.5 & absent & absent \\
\hline 26 & & 09.01 .12 & 7.97 & 41.4 & 98.3 & 1.81 & 6.56 & 2.18 & 94.8 & absent & absent \\
\hline 27 & & 23.01 .12 & 2.96 & 2.62 & 8.76 & 0.22 & 1.18 & 0.23 & 10 & absent & absent \\
\hline 28 & & 13.02 .12 & 3.48 & 13.6 & 29.2 & 0.96 & 1.55 & 1.05 & 43 & absent & absent \\
\hline 29 & & 20.02 .12 & 3.96 & 12.24 & 36.88 & 0.78 & 1.16 & 0.57 & 17 & absent & absent \\
\hline 30 & \multirow{6}{*}{ Spring } & 19.03 .12 & 9.18 & 18.8 & 60.9 & 1.77 & 2.27 & 1.88 & 80 & absent & absent \\
\hline 31 & & 02.04 .12 & 7.31 & 21 & 109 & 1.62 & 1.57 & 3.5 & 111 & absent & absent \\
\hline 32 & & 16.04 .12 & 6.31 & 38.2 & 112.8 & 1.59 & 2.22 & 2.27 & 82.4 & absent & absent \\
\hline 33 & & 30.04 .12 & 8.08 & 28.4 & 123.1 & 1.79 & 2.03 & 2.82 & 98 & absent & absent \\
\hline 34 & & 14.05 .12 & 4.315 & 9.4 & 23.65 & 0.79 & 1 & 1.54 & 39 & absent & absent \\
\hline 35 & & 28.05 .12 & 7.635 & 37.1 & 82.1 & 1.54 & 2.46 & 1.86 & 88 & present & absent \\
\hline
\end{tabular}

winter (Table 5). The average values of $\mathrm{N}$ and $\mathrm{BOD}$ remained relatively constant in summer and autumn: 5.76 $\mathrm{g} / \mathrm{kg}$ in summer and $5.66 \mathrm{~g} / \mathrm{kg}$ in autumn for $\mathrm{N}$ and $21.66 \mathrm{~g} / \mathrm{kg}$ in summer and $21.40 \mathrm{~g} / \mathrm{kg}$ in autumn for BOD. The average COD values ranged between 37.02 and $85.26 \mathrm{~g} / \mathrm{kg}$ (Table 2). As in the case of N, BOD, P, and dry mass, the lowest average values were found in winter and the highest in spring (Fig. 1).

The average $\mathrm{Ca}$ values ranged between 1.24 and 2.63 $\mathrm{g} / \mathrm{kg}$. As in the case of $\mathrm{N}, \mathrm{BOD}, \mathrm{P}$, and dry mass, the lowest average values were found in winter and the highest in spring.

Only in the case of potassium the average values remained at nearly the same level throughout the year (Fig. 1). The segments shown in Fig. 1 fall nearly on a straight line. The average $\mathrm{K}$ values (Table 2) ranged between 1.92 and $2.02 \mathrm{~g} / \mathrm{kg}$. Throughout the year, the highest values were observed for dry mass $(67.06 \mathrm{~g} / \mathrm{kg})$ and COD $(57.73 \mathrm{~g} / \mathrm{kg})$, whereas the lowest values were observed for P (1.22 g/kg); a somewhat higher but rela- 
A

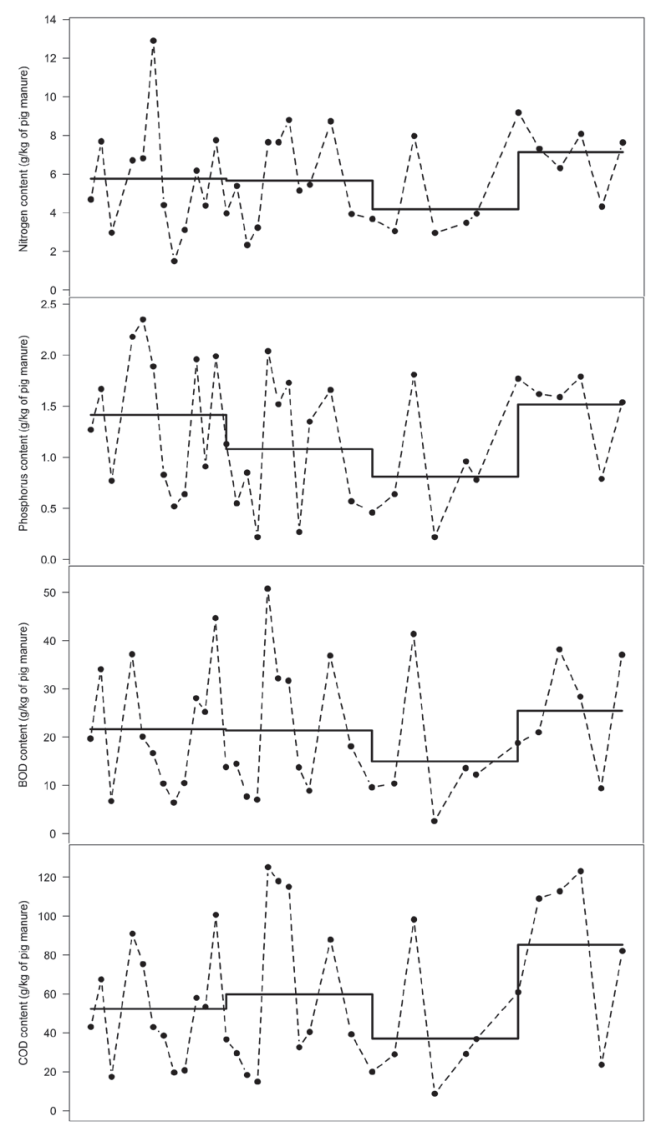

$\mathrm{B}$

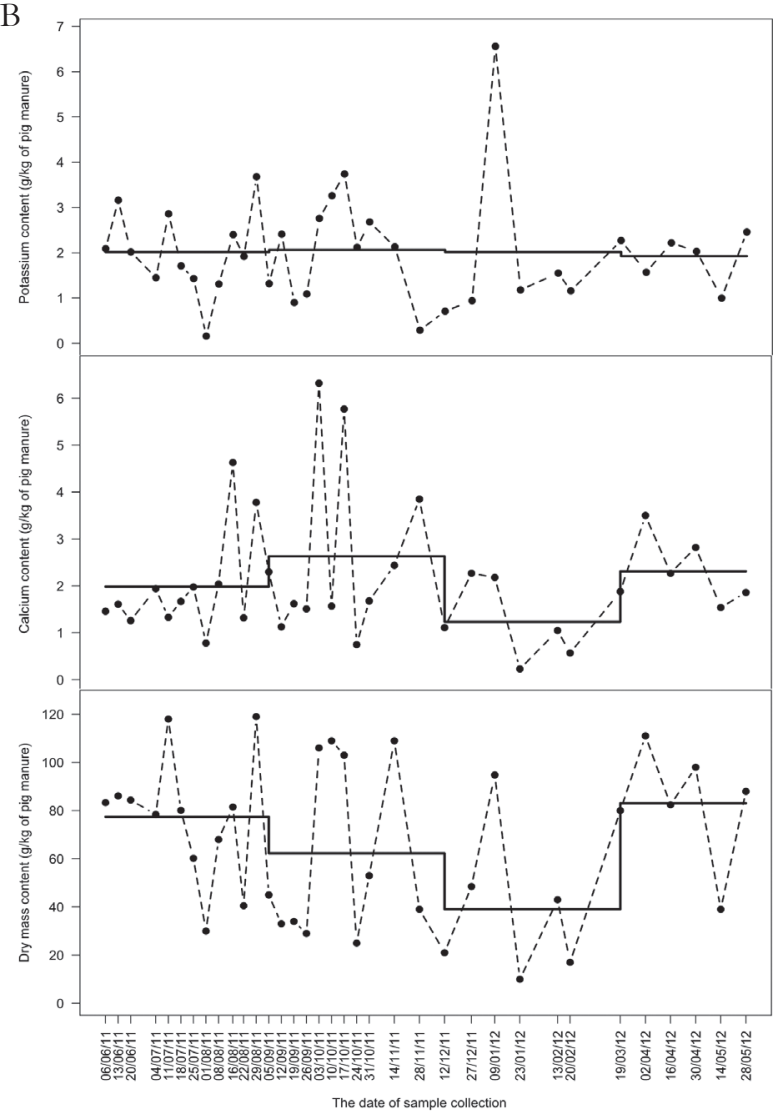

Figure 1. Changes in:

(A) nitrogen, $\mathrm{BOD}_{5}, \mathrm{COD}$, phosphorus, (B) potassium, calcium and dry mass content according to the date of slurry collection

tively comparable level was observed for $\mathrm{K}(2.02 \mathrm{~g} / \mathrm{kg})$ and $\mathrm{Ca}(2.11 \mathrm{~g} / \mathrm{kg})$.

The microbiological analysis identified Salmonella bacilli in three samples only and live parasite eggs in one sample.

The results of the variance analysis for the individual parameters are shown in the last column of Table 3. The null hypothesis of the variance analysis test assumes that the average parameter values are equal throughout the year. None of the cases analyzed contradicted the null hypothesis. The parameters of COD, P, and dry mass, for which the $\mathrm{p}$-values were $0.133,0.124$, and 0.054 , respectively, were the closest to statistical significance.

The Pearson linear correlation coefficient was used in the next stage of the analysis (Table 4). All correlations except the one with smallest correlation coefficient (i.e., the correlation between $\mathrm{Ca}$ and $\mathrm{K}$ ) were statistically significant.

The highest correlation coefficient was found between COD and BOD (0.88). A strong interdependence also occurred between dry mass and $\mathrm{P}$ (0.86), dry mass and COD (0.82), $\mathrm{P}$ and $\mathrm{N}(0.79), \mathrm{P}$ and COD (0.79), $\mathrm{P}$ and BOD (0.76), and BOD and dry mass (0.74). A moderately strong correlation occurred between BOD and $\mathrm{N}(0.66), \mathrm{BOD}$ and $\mathrm{K}(0.66)$, dry mass and $\mathrm{K}(0.62), \mathrm{COD}$ and $\mathrm{Ca}(0.61), \mathrm{COD}$ and $\mathrm{K}$ (0.60), $\mathrm{P}$ and $\mathrm{K}(0.59)$, and $\mathrm{K}$ and $\mathrm{N}(0.58)$. Ca and $\mathrm{N}$ as well as $\mathrm{K}$ and $\mathrm{Ca}$ displayed weak correlations: 0.40 and 0.29 , respectively.

These analyses identified increasing or decreasing tendencies linking pairs of parameters. The COD and $\mathrm{BOD}$ parameters can be used to determine the purity of the slurry. The strong interdependence between these two parameters was demonstrated by their high correlation coefficient (0.88). Additionally, the strong correlations between dry mass and $\mathrm{P}$, dry mass and COD, and dry mass and BOD provide important information. These correlations allow us to hypothesize that a higher dry mass content is associated with a higher level of BOD, COD, as well as a higher level of phosphorus, which is a valuable constituent of fertilizers. The strong correlations between phosphorus and COD, BOD, and $\mathrm{N}$ help to identify tendencies in the content of other constituents. Specifically, a higher $\mathrm{P}$ content is associated with higher levels of COD, $\mathrm{BOD}$, and $\mathrm{N}$.

Table 5 shows the regression coefficients for statistically significant independent variables in the regression models created for the dependent variables given in the first column of the table. The last two columns of Table 5 contain measures of the goodness of fit, i.e., the coefficient of determination and the standard deviation of the residuals. It can be assumed that the regression models created for BOD, COD, P and dry mass indicate a relatively good fit. In the case of the remaining parameters, the fit is unsatisfactory.

The regression models for $\mathrm{BOD}, \mathrm{COD}, \mathrm{P}$ and dry mass enable us to predict the value of a given parameter based on knowledge about other parameters. For example, it is possible to predict the value of $\mathrm{BOD}_{5}$ by determining COD.

The analysis of the average values of $\mathrm{N}, \mathrm{BOD}, \mathrm{P}$ and dry mass in different seasons has shown that these parameters tend to decrease systematically between spring 
Table 3. Descriptive statistics of the variables (average, standard deviation) and analysis of variance results.

\begin{tabular}{|c|c|c|c|c|c|c|}
\hline \multirow{4}{*}{ Variable } & \multirow{2}{*}{ Total } & \multicolumn{4}{|l|}{ Season } & \multirow{4}{*}{$p$-value } \\
\hline & & Summer & Autumn & Winter & Spring & \\
\hline & \multicolumn{5}{|c|}{ Number of measurements } & \\
\hline & 35 & 12 & 11 & 6 & 6 & \\
\hline $\mathrm{N}$ & $5.69(2.47)$ & $5.76(3.00)$ & $5.66(2.24)$ & $4.18(1.89)$ & $7.14(1.67)$ & 0.234 \\
\hline BOD & $21.09(12.89)$ & $21.66(12.49)$ & $21.40(14.32)$ & $14.98(13.49)$ & $25.48(11.21)$ & 0.576 \\
\hline COD & $57.73(36.83)$ & $52.38(27.42)$ & $59.85(42.68)$ & $37.02(31.52)$ & $85.26(37.82)$ & 0.133 \\
\hline$P$ & $1.22(0.62)$ & $1.42(0.66)$ & $1.08(0.63)$ & $0.81(0.55)$ & $1.52(0.37)$ & 0.124 \\
\hline K & $2.02(1.18)$ & $2.02(0.94)$ & $2.06(1.06)$ & $2.02(2.24)$ & $1.92(0.54)$ & 0.997 \\
\hline $\mathrm{Ca}$ & $2.11(1.36)$ & $1.98(1.11)$ & $2.63(1.88)$ & $1.24(0.83)$ & $2.31(0.73)$ & 0.232 \\
\hline Dry mass & $67.06(32.64)$ & $77.46(26.21)$ & 62.27 (36.08) & $39.05(31.21)$ & 83.07 (24.41) & 0.054 \\
\hline
\end{tabular}

Table 4. Matrix of the Pearson linear correlation coefficients.

\begin{tabular}{llllllll}
\hline Variable tested & $\mathrm{N}$ & $\mathrm{BOD}$ & $\mathrm{COD}$ & $\mathrm{P}$ & $\mathrm{K}$ & $\mathrm{Ca}$ & Dry mass \\
\hline $\mathrm{N}$ & & 0.66 & 0.70 & 0.79 & 0.58 & 0.40 & 0.71 \\
$\mathrm{BOD}$ & 0.66 & & 0.88 & 0.76 & 0.65 & 0.59 & 0.74 \\
$\mathrm{COD}$ & 0.70 & 0.88 & & 0.79 & 0.60 & 0.61 & 0.82 \\
\hline $\mathrm{P}$ & 0.79 & 0.76 & 0.79 & & 0.59 & 0.51 & 0.86 \\
$\mathrm{~K}$ & 0.58 & 0.65 & 0.60 & 0.59 & & 0.29 & 0.62 \\
\hline $\mathrm{Ca}$ & 0.40 & 0.59 & 0.61 & 0.51 & 0.29 & 0.55 & \\
\hline Dry mass & 0.71 & 0.74 & 0.82 & 0.86 & 0.62 & 0.55 & \\
\hline
\end{tabular}

Table 5. Results of multiple regression modeling.

\begin{tabular}{|c|c|c|c|c|c|c|c|c|c|c|}
\hline \multirow{2}{*}{$\begin{array}{l}\text { Dependent } \\
\text { variable }\end{array}$} & \multirow{2}{*}{ Intercept } & \multicolumn{7}{|c|}{$\begin{array}{l}\text { Regression coefficients for independent variables } \\
(\mathrm{x} \text { - not significant) }\end{array}$} & \multirow{2}{*}{$\mathrm{R}^{2}(\%)$} & \multirow{2}{*}{$\begin{array}{l}\text { Root Mean } \\
\text { Squared } \\
\text { Error }\end{array}$} \\
\hline & & $\mathrm{N}$ & BOD & COD & $\mathrm{P}$ & $\mathrm{K}$ & $\mathrm{Ca}$ & Dry mass & & \\
\hline $\mathrm{N}$ & 1.872 & $x$ & $x$ & $x$ & 3.123 & $x$ & $x$ & $x$ & 62 & 1.55 \\
\hline BOD & 1.447 & $x$ & $x$ & 0.267 & $x$ & 2.087 & $x$ & $x$ & 80 & 6 \\
\hline COD & -6.78 & $x$ & 1,734 & $x$ & $x$ & $x$ & $x$ & 0.417 & 84 & 15.4 \\
\hline$P$ & -0.046 & 0.0759 & 0.0096 & $x$ & $x$ & $x$ & $x$ & 0.0095 & 82 & 0.28 \\
\hline K & 0.4506 & $x$ & 0.0396 & $x$ & $x$ & $x$ & $x$ & 0.0109 & 47 & 0.89 \\
\hline $\mathrm{Ca}$ & 0.795 & $x$ & 0.063 & $x$ & $x$ & $x$ & $x$ & $x$ & 35 & 1.11 \\
\hline Dry mass & 11.862 & $x$ & $x$ & 0.324 & 29.823 & $x$ & $x$ & $x$ & 79 & 15.5 \\
\hline
\end{tabular}

and winter. An analogous situation occurred in the case of COD and calcium, where the lowest values were also recorded in winter. Time at which the highest values occur represents a somewhat different situation because the highest content of COD was observed in spring, whereas the highest content of $\mathrm{Ca}$ was recorded in autumn. The values of potassium remained stable throughout the year.

The results have shown a strong interdependence between the variables tested, consistently occurred between COD and BOD, whereas the lowest occurred consistently between $\mathrm{K}$ and $\mathrm{Ca}$ and once between $\mathrm{Ca}$ and $\mathrm{N}$.

\section{Acknowledgements}

This study has been carried out in the framework of the Development Project No.14-0003-10/2010 granted by the National Centre for Research and Development

\section{REFERENCES}

Act on fertilizers and fertilization of 10 July 2007 (2007) Pol J Laws No 147, Item 1033

Bertora C, Alluvione F, Zavattaro L, van Groenigen JW, Velthof G, Grignani C (2008) Pig slurry treatment modifies slurry composition, $\mathrm{N}_{2} \mathrm{O}$, and $\mathrm{CO}_{2}$ emissions after soil incorporation. Soil Biol Biochem 40: 1999-2006.

Cotta MA, Whitehead TR Zeltwanger RL (2003) Isolation, characterization and comparison of bacteria from swine faeces and manure storage pits. Environ Microbiol 5: 737-745.

Czop M (2011) Biogenic potential of waste from pig stock. Arch Econ Waste Environ Prot 13: 53-64 (in Polish).

De la Torre AI, Jimenez JA, Carballo M, Fernandez C, Roset J, Munoz J (2000) Ecotoxicological evaluation of pig slurry. Chemosphere 41: 1629-1635.

Głąb K, Gondek K (2008) Effect of organic amendments on morphometric properties of macropores in stagnic glyesol soil. Pol J Environ Stud 17: 209-214.

Hus S, Kutera J (1998) Agricultural treatment and use of wastewater and liquid manure. Wroclaw University of Agriculture Edition, Wrocław (in Polish). 
Hsu JH, Lo SL (1999) Chemical and spectroscopic analysis of organic matter transformations during composting of pig manure. Environ Pollution 104: 189-196.

Kowalski Z, Makara A, Hoffmann J, Hoffmann K (2012) Obtaining of NPK type fertilizers from pig manure using clean technology methods. Report from ReD project No. 14-0003-10/2010, Cracow University of Technology (in Polish).

Krawczyk W, Walczak J (2010) Biogenic potential of manure as a source of ammonia emissions and environmental risk. Res Ann Zootech 37: 187-193.

Kuczyński T (2002) The emission of ammonia from farm buildings and the environment. WNT Edition, Zielona Góra (in Polish).

Lens P, Hamelers B, Hoitink H, Bidlingmaier W (2004) Resource recovery and reuse in organic solid waste management. pp 249-261. IWA Publishing.

Libudzisz Z, Kowal K, Żakowska Z (2008) Technical microbiology. Microorganisms in biotechnology, environmental protection and food production. PWN Edition, Warszawa (in Polish).

Magrel L (2004) Predicting methane fermentation of the mixture of sewage sludge and manure. University of Technology Edition, Białystok (in Polish).

Moral R, Perez-Murcia MD, Perez-Espinosa A, Moreno-Caselles J, Paredes C (2005) Estimation of nutrient values of pig slurries in Southeast Spain using easily determined properties. W aste Manage 25: $719-725$.

Oudendag DA, Luesink HH (1998) The Manure Model: minerals (N, P and K), ammonia emission, heavy metals and the use of fertilizer in Dutch agriculture. Environ Pollut 102: 241-246.

Pawełczyk A, Muraviev D (2003) Integrated treatment technology for liquid waste from pig farms. Przem Chem 82: 861-863 (in Polish).
Prapaspongsa T (2010) Sustainable piggery waste management: a study based on examples and cases from Denmark and Thailand Section of Environmental Engineering. Aalborg University. Ph.D. Dissertation.

R Development Core Team (2010) R: A language and environment for statistical computing. R Foundation for Statistical Computing, Vienna, Austria. ISBN 3-900051-07-0, URL http://www.R-project.org

Rufete B, Perez-Murcia MD, Perez-Espinosa A, Moral R, Moreno-Caselles J, Paredes C (2006) Total and faecal coliform bacteria persistence in a pig slurry amended soil. Livest Sci 102: 211-215.

Rulkens WH, Klapwijk A, Willersb, HC (1998) Recovery of valuable nitrogen compounds from agricultural liquid wastes: potential possibilities, bottlenecks and future technological challenges. Environ Pollut 102 S1: 727-735.

Sánchez M, González JL (2005) The fertilizer value of pig slurry. I. Values depending on the type of operations. Bioresour Technol 96: 1117-1123.

Sorensen P, Amato M (2001) Remineralisation and residual effects of $\mathrm{N}$ after application of pig slurry to soil. Eur J Agron 16: 81-95.

Szynkowska MI, Zwoździak J (2010) Contemporary problems of odors, ed. WNT, Warsaw (in Polish).

Taylor DC (1994) Livestock manure production and disposition: South Dakota Feedlots-Farms-Ranches. Economics Research Report 94-4, November 1994. Brookings, SD: Economics Department, South Dakota State University.

Troeh FR, Thompson LM (1993) Soils and Soil Fertility, 5th edn. Oxford University Press, New York. 